\title{
Compensatory lung growth: protein, DNA and RNA lung contents in undernourished trilobectomized rats ${ }^{1}$
}

\author{
Crescimento pulmonar compensatório: conteúdos pulmonares de proteína, DNA e \\ RNA em ratos subnutridos trilobectomizados
}

\author{
Raul Lopes Ruiz Júnior ${ }^{2}$, Lídia Raquel de Carvalho ${ }^{3}$, Antonio José Maria Cataneo ${ }^{4}$ \\ 1. Thoracic Surgery, Department of Orthopedics and Surgery and Department of Biostatistics, Bioscience Institute, State University of Sao \\ Paulo (UNESP). Botucatu - SP, Brazil. \\ 2. Assistent Professor Thoracic Surgery, Department of Orthopedics and Surgery, State University of Sao Paulo (UNESP). Botucatu - SP, \\ Brazil. \\ 3. Assistant Professor Department of Biostatistics, Bioscience Institute, UNESP. Botucatu - SP, Brazil. \\ 4. Associate Professor Thoracic Surgery, Department of Orthopedics and Surgery, UNESP. Botucatu - SP, Brazil.
}

\begin{abstract}
Purpose: To demonstrate compensatory lung growth (CLG) by lung contents of proteins, DNA, and RNA in undernourished young adult rats, submitted to pulmonary trilobectomy. Methods: We used 137 male Wistar rats, randomly distributed into 9 groups; they were submitted to three treatments (control, thoracotomy, and trilobectomy), and sacrificed at three different times (7, 30, and 90 days). In trilobectomy we removed the right median, accessory, and caudal lobes. We studied lung proteins, DNA, and RNA contents. Results: In the cranial lobe and left lung, protein content was higher in trilobectomized rats however there was insufficient CLG to make up for the loss. The increase of DNA in the cranial lobe and left lung of trilobectomized rats was sufficient to compensate for this loss, resulting in a similar content to controls. RNA content in trilobectomized rats, was higher in the cranial lobe and left lung, more efficient in the cranial lobe, but less than in the other groups. Conclusions: CLG occurred in trilobectomized rats, probably with cell hyperplasia and little hypertrophy, due to the large DNA compensation and small RNA compensation. This was markedly different to wellnourished animals, who had pronounced hypertrophy.
\end{abstract}

Key words: lung/growth and development, nutrition disorders, Wistar rats.

\section{RESUMO}

Objetivo: demonstrar se ocorre crescimento pulmonar compensatório (CPC) representado pelos conteúdos de proteínas, DNA e RNA no rato adulto jovem, subnutrido, submetido à trilobectomia pulmonar. Métodos: Utilizamos 137 ratos “Wistar”, machos, distribuídos por sorteio, em 9 grupos, submetidos a três tratamentos (controle, toracotomia, trilobectomia), sacrificados em três momentos (7, 30 e 90 dias). Na trilobectomia foram extirpados os lobos médio, acessório e caudal direitos. Variáveis estudadas: conteúdos pulmonares de proteínas, DNA e RNA. Resultados: No lobo cranial e pulmão esquerdo o conteúdo protéico foi maior nos trilobectomizados. Ocorreu CPC insuficiente para suprir a perda desta variável, sendo menor nos pulmões dos trilobectomizados. O incremento nos conteúdos de DNA do lobo cranial e pulmão esquerdo dos trilobectomizados foram suficientes para compensar a perda desta variável, resultando num conteúdo de DNA dos pulmões semelhante aos controle. O conteúdo de RNA, nos trilobectomizados, foi maior no lobo cranial e pulmão esquerdo, com maior eficiência no primeiro, insuficiente para que se aproximassem aos obtidos nos demais grupos, ficando menores. Conclusões: Nos trilobectomizados ocorreu CPC, provavelmente com hiperplasia celular e pouca hipertrofia, devido a grande compensação do DNA e pequena do RNA. Esta foi a grande diferença quando comparamos este resultado ao obtido com animais nutridos, que apresentavam hipertrofia pronunciada.

Descritores: pulmão/crescimento, transtornos nutricionais, ratos wistar.

\section{Introduction}

In an attempt to fill the pleural cavity after lung resection, the remaining elements of the pulmonary parenchyma distend causing a change in cell shape favouring important metabolic responses that increase gene expression $^{6}$; this stimulates protein synthesis and cell division ${ }^{10}$. Pulmonary insufflation and increased blood flow in the remaining lung, which occur soon after pulmonary resection, induce early gene expression which could be prerequisites for initiating CLG. Similar modifications occur at the RNAm levels, produced from these genes in isolated lungs submitted to exogenic insufflation and perfusion ${ }^{6}$. These genes which are expressed in the earliest stages at the start of compensatory growth, could have a regulatory function during the initial phase of pulmonary growth after 
pneumonectomy in rats ${ }^{4}$. Biochemical studies of DNA, RNA, and protein content could answer the question of whether there is only alveolar hyperinflation, or if in fact intracellular substances are deposited (hypertrophy) or cell numbers increase (hyperplasia). Increased DNA content, which is predominantly nuclear, suggests an increase in cell numbers, this is a marker of cell hyperplasia, while RNA and protein content are markers of hypertrophic growth ${ }^{10}$. In an earlier study with young adult well-nourished rats, we demonstrated efficient CLG when content was RNA and protein, and less effective when it was DNA. Therefore CLG seems to occur by cellular hypertrophy ${ }^{13,11}$. Does CLG occur in undernourished young adult rats submitted to lung resection? If so, what is the biochemical behaviour?

The objective was to study CLG represented by DNA, RNA, and protein content in undernourished young adult rats submitted to lung trilobectomy.

\section{Methods}

One hundred and thirty-seven healthy male Wistar rats were used; they were 75 days old and weighed approximately $175 \mathrm{~g}$. Throughout the study, they were kept in a closed room with 12-hour per day artificial light cycle, individually housed in metal cages, received only $10 \mathrm{~g}$ rat chow per day and water ad libitum. Animals were submitted to fasting in the 24 hours prior to anaesthesia and surgery. This study was approved by the Ethics Committee for Experimental Animals (CEEA), Botucatu School of Medicine - UNESP.At the beginning of the 14 day conditioning period, rats were weighed and examined. From this time on their daily food intake was rationed. A pilot study had demonstrated that normal rats in this stage of development ingest around $30 \mathrm{~g}$ Labina $^{\circledR *}$ per day. According to this feed reduction model, rats received $33 \%$ of the normal daily quantity, around $10 \mathrm{~g}$, throughout the conditioning period and duration of the experiment. After the 14-day conditioning period, we saw that rats showed signs of undernourishment (reduced weight gain). Rats were randomly distributed into 9 experimental groups and submitted to three treatments (None $=\mathbf{C O N}$, Thoracotomy $=\mathbf{T O R}$, and Trilobectomy $=$ TRI); they were sacrificed at three different times (7, 30, and 90 days) with collection of material for protein, DNA, and RNA content from three different lung tissue samples: A Left Lung Parenchyma; B - Cranial Lobe Parenchyma, and C - Pooled Accessory, Median, and Caudal Lobes.

There were 11, 15, and 13 rats in the control, 20,18, and 14 in the thoracotomy, and 14, 14, and 18 in the trilobectomy groups at 7, 30, and 90 days respectively.

Rats were submitted to general anaesthesia by intraperitoneal injection of sodium pentobarbital (30mg/kg).

Airway maintenance was by orotracheal intubation with an $8.2 \mathrm{~cm}$ long PE160 polyethylene tube, with help from Lshaped blades and a cold light source.

Ventilation was maintained manually using an AMBU (Automatic Manual Breathing Unit).

Under clean conditions (trichotomy and iodizede alcohol) trilobectomy was performed through a large thoracotomy in the seventh right intercostal space. The

\footnotetext{
* Agribrands Purina do Brasil Ltda.
}

Caudal lobe broncho-vascular pedicule was isolated and tied with $n^{\circ} 10$ cotton suture. The same procedure was performed for median and accessory lobes. After trilobectomy, the left lung, 34\% pulmonary volume, and the cranial lobe, $11 \%$ pulmonary volume both remained intact ${ }^{2}$ (Figure 1).

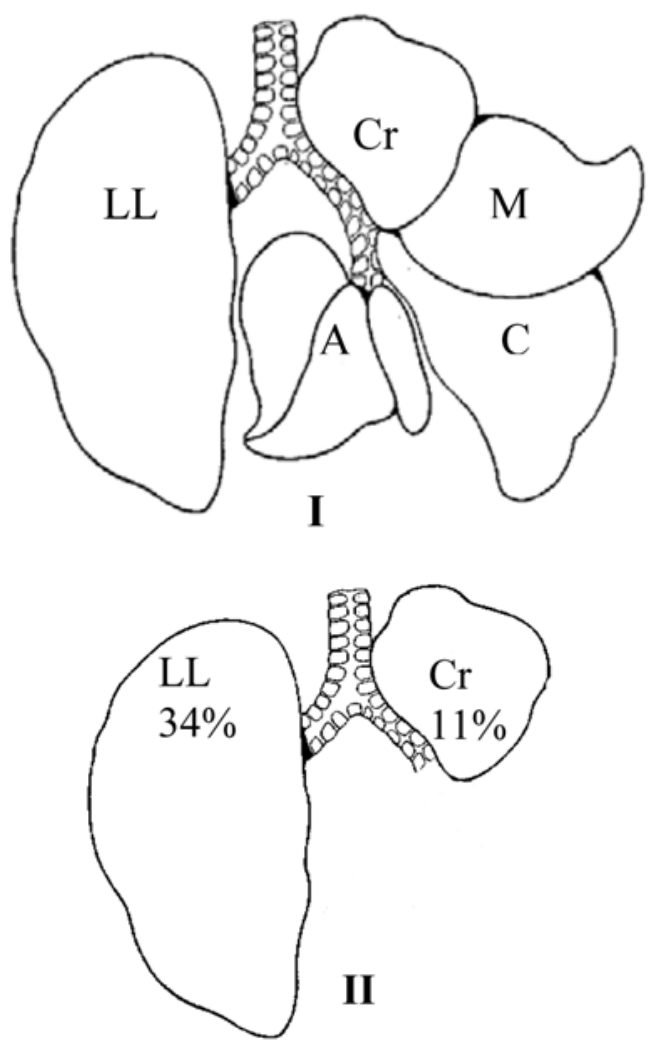

FIGURE 1 - I) Anatomy of Rat pulmonary lobes: A = Accessory lobe, $\mathrm{C}=$ Caudal lobe, $\mathrm{Cr}=$ Cranial lobe, $\mathrm{LL}=$ left lung, $\mathrm{M}=$ median lobe.

II) Trilobectomy, remaining pulmonary parenchema: $\mathrm{LL}=$ left lung $(34 \%)$; $\mathrm{Cr}=$ Cranial lobe (11\%).

Closing the thoracic wall was performed in three layers, with hyperinsuflation of the remaining lung to the end of the muscular wall to remove air from the cavity. Ribs, muscule, subcutaneous and skin, were closed by continuous $n^{\circ} 10$ cotton suture.

At sacrifice, rats were weighed and anaesthetized as described above. Laparotomy and then exsanguination was performed by total section of the inferior vena cava and abdominal aorta. Median sternotomy was by block resection of the heart and lungs, the latter being carefully dissected, weighed on an analytic balance, and used to determine protein content by total nitrogen as per MicroKjeldahl ${ }^{1}$; DNA content by the Burton Diphenylamine Method (1956) modified by Giles \& Myers ${ }^{7}$; RNA content by the Schmidt and Thannhauser method (1945) modified by Munro \& Fleck ${ }^{9}$.

The cranial lobe, left lung, and right lung were individually studied for Protein (mg), DNA ( $\mu \mathrm{g})$, and RNA ( $\mu$ g) content. The sum of values from the left and right 
lungs in the control (CON) and thoracotomy (TOR) groups, or the left lung and cranial lobe in the trilobectomy (TRI) group, were respectively called Protein (mg), DNA ( $\mu \mathrm{g})$, and RNA $(\mu \mathrm{g})$ content of the lungs. Statistical Analysis for normally distributed variables was by Analysis of Variance for entirely randomised variables ${ }^{15}$ with:

$\mathbf{A}=$ treatment: CON; TOR; TRI;

$\mathbf{B}=$ time: A: at 7 days; B: at 30 days; $\mathrm{C}$ : at 90 days.

In all hypotheses tested, the calculated F statistic was considered significant when $\mathrm{p}<0.05$. Difference between pairs of means was verified by the Tukey test with minimum significant difference calculated for $\mathrm{a}=0.05$. For variables with a normal distribution, the non-parametric Kruskal-Wallis test was used with the Dunn test to compare groups between each moment, and moments between each group 5 .

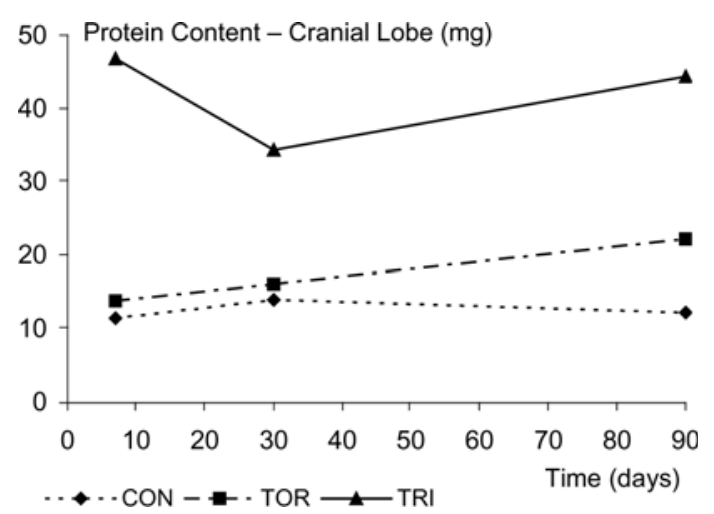

FIGURE 2 - Protein content of the cranial lobe (mg). Treatment: $\mathrm{p}<0.05$; $(\mathrm{CON}=\mathrm{TOR})<\mathrm{TRI}$.

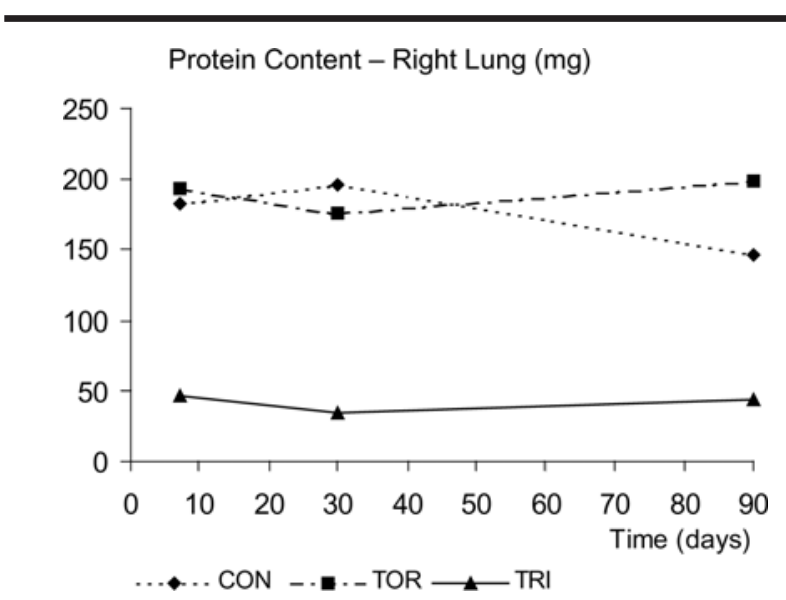

FIGURE 4 - Protein content of the right lung (mg). Treatment: $\mathrm{p}<0.05$; $(\mathrm{CON}=\mathrm{TOR})>\mathrm{TRI}$.

\section{DNA Content:}

In TRI rats, DNA content of the cranial lobe was significantly higher at 7 and 90 days. In the left lung it was significantly higher at all three studied times (Figures 6 and 7).

In the right lung, similarly to protein content, DNA content was also significantly less in TRI rats, showing that the increase in cranial lobe was not sufficient to compensate for the other three right lobes (Figure 8), but

\section{Results}

\section{Protein Content:}

Protein content of the cranial lobe and left lung between the three groups was significantly higher in TRI rats (Figures 2 and 3). As right lung protein content was less in TRI rats, the increase in cranial lobe was not sufficient to compensate for the loss of the other three right side lobes (Figure 4), and when compared to protein content of both lungs, between the three groups, it was significantly less in TRI rats, showing that even though occurring in both left lung and cranial lobe, it was still not sufficient to compensate for the loss of the three right lung lobes in trilobectomized rats (Figure 5).

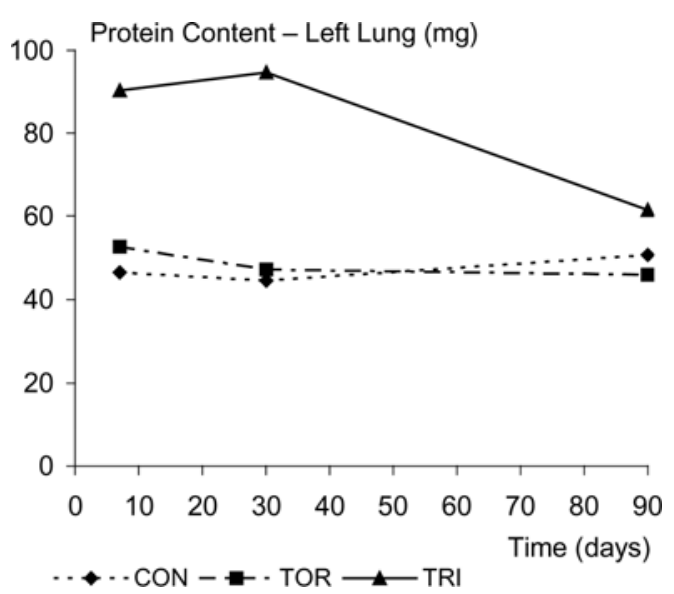

FIGURE 3 - Protein content of the left lung (mg). Treatment: $\mathrm{p}<0.05 ;(\mathrm{CON}=\mathrm{TOR})<\mathrm{TRI}$.

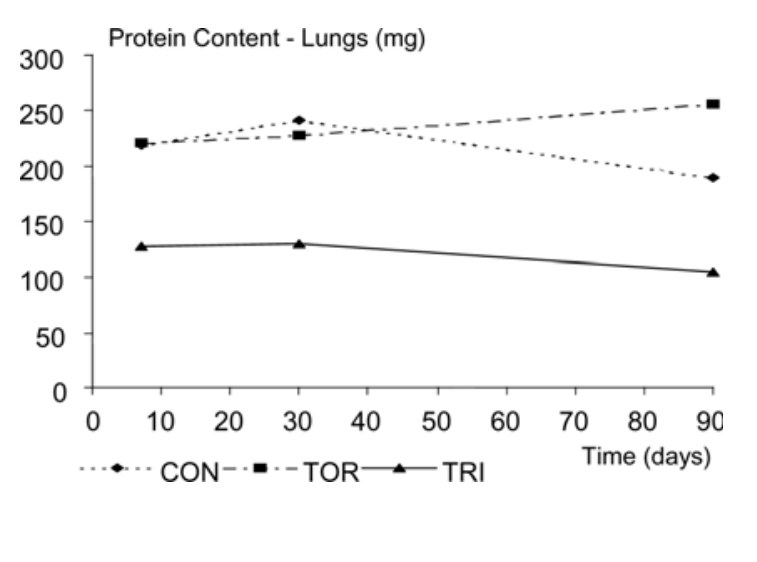

FIGURE 5 - Protein content of lungs (mg). Treatment: $\mathrm{p}<0.05$; $(\mathrm{CON}=\mathrm{TOR})>\mathrm{TRI}$.

when compared to DNA content in both lungs, the control group and TRI group were similar, showing that increase in the cranial lobe and left lung were sufficient to compensate for the loss of the three lobes (Figure 9).

RNA content of the cranial lobe and left lung was also significantly higher in TRI rats (Figures 10 and 11), however in the right lung, similarly to protein and DNA, it was significantly less, showing that the increase in cranial lobe 
was not sufficient to compensate for the loss of the other three right side lobes (Figure 12). RNA content of both lungs was significantly less in TRI rats, showing that the

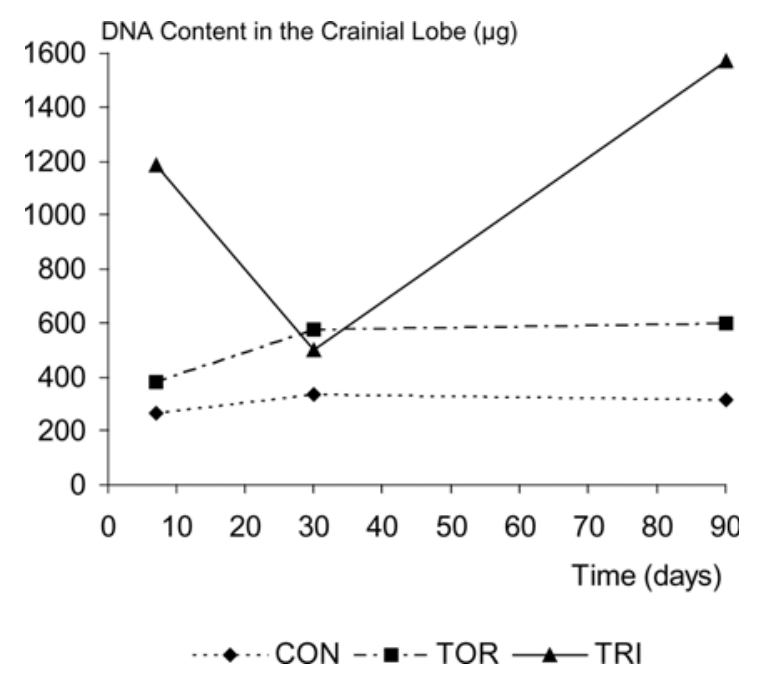

FIGURE 6 - DNA content in the cranial lobe ( $\mu$ g). Treatment: At 7 and 90 days, $\mathrm{p}<0.05$; $(\mathrm{CON}=\mathrm{TOR})<\mathrm{TRI}$. At 30 days, $\mathrm{p}>0.05 ; \mathrm{CON}=\mathrm{TOR}=\mathrm{TRI}$.

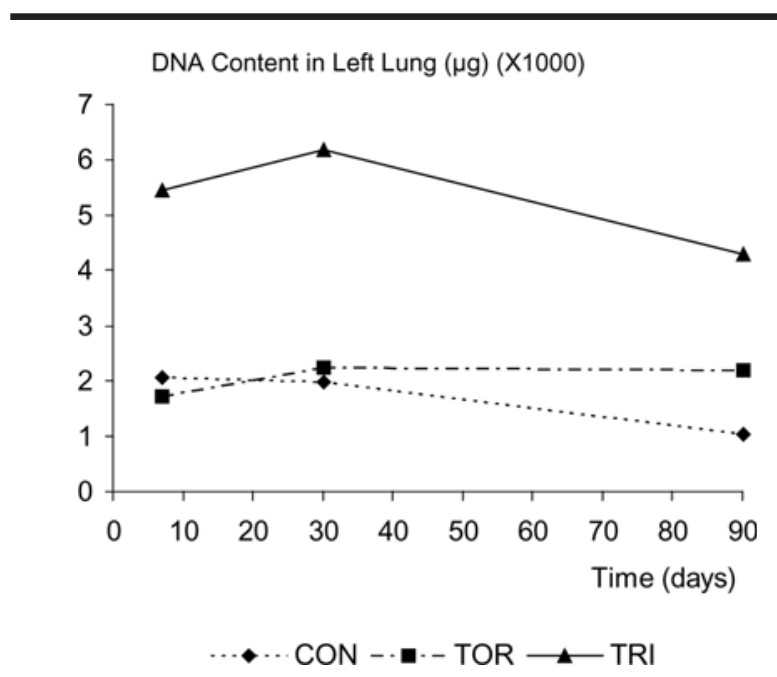

FIGURE 7 - DNA content in the left lung $(\mu \mathrm{g})$. Treatment: $\mathrm{p}<0.05$; $(\mathrm{CON}=\mathrm{TOR})<\mathrm{TRI}$.

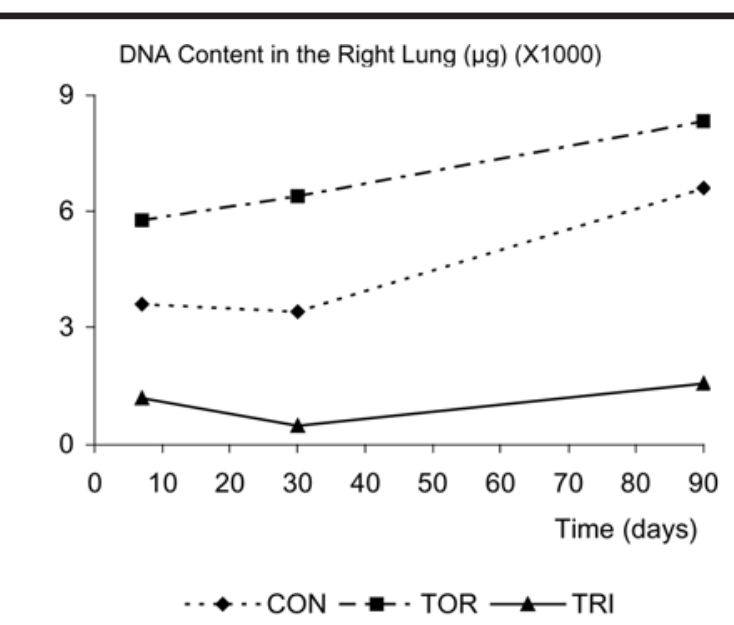

FIGURE 8 - DNA content in the right lung $(\mu g)$. Treatment: $\mathrm{p}<0.05 ;(\mathrm{CON}=\mathrm{TOR})>\mathrm{TRI}$. increases in cranial lobe and left lung were not sufficient to compensate for the loss of the three lobes (Figure 13); this was similar to protein content.

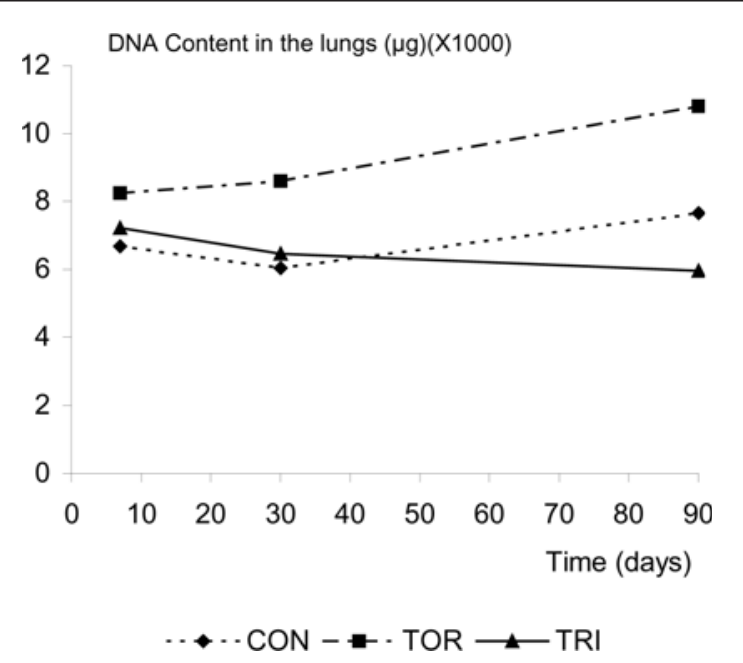

FIGURE 9 - DNA content in the lungs $(\mu \mathrm{g})(\mathrm{x} 1000)$. Treatment: $\mathrm{p}<0.05 ;(\mathrm{CON}=\mathrm{TRI})<\mathrm{TOR}$.

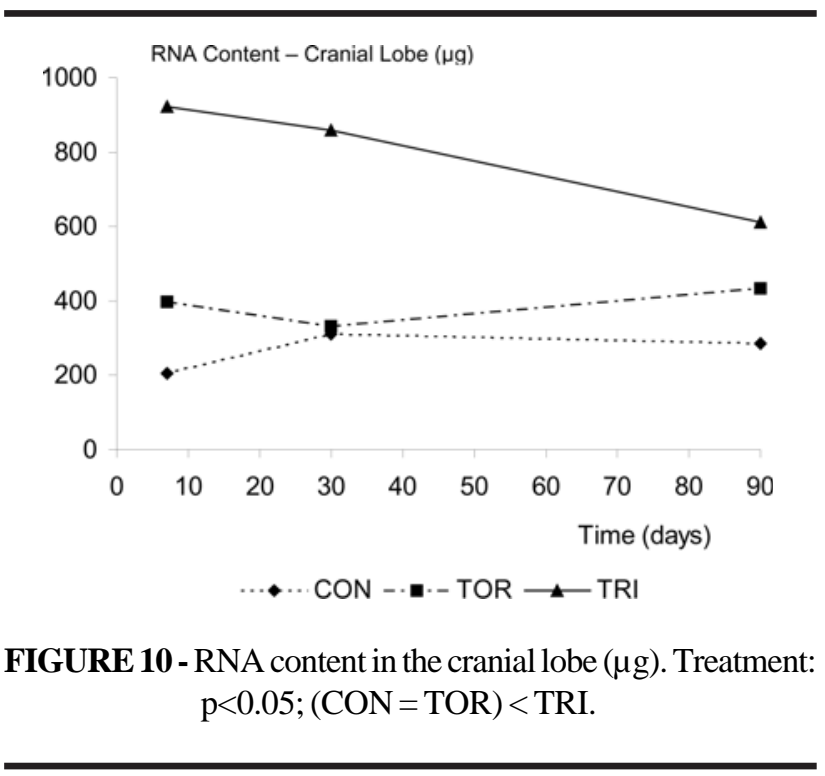

RNA Content - Left Lung $(\mu \mathrm{g})$

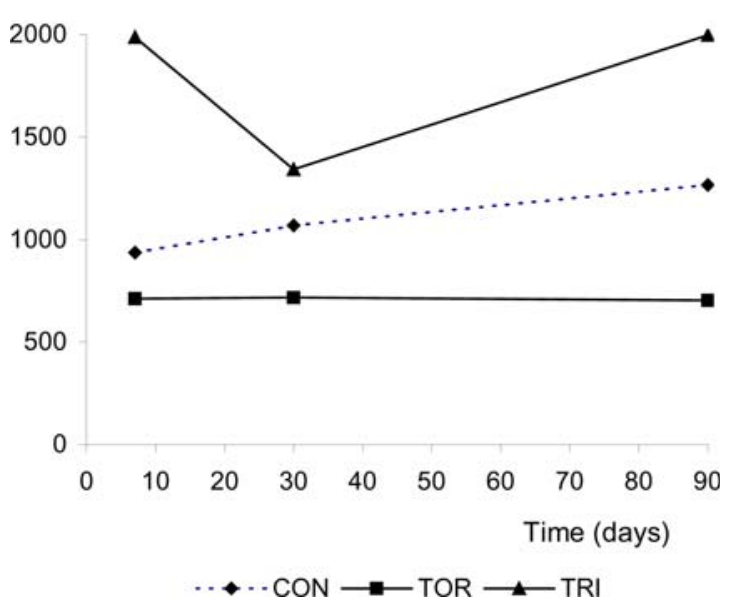

FIGURE 11 - RNA content of the left lung $(\mu \mathrm{g})(\mathrm{x} 1000)$. Treatment: $\mathrm{p}<0.05 ;(\mathrm{CON}=\mathrm{TOR})<\mathrm{TRI}$. 


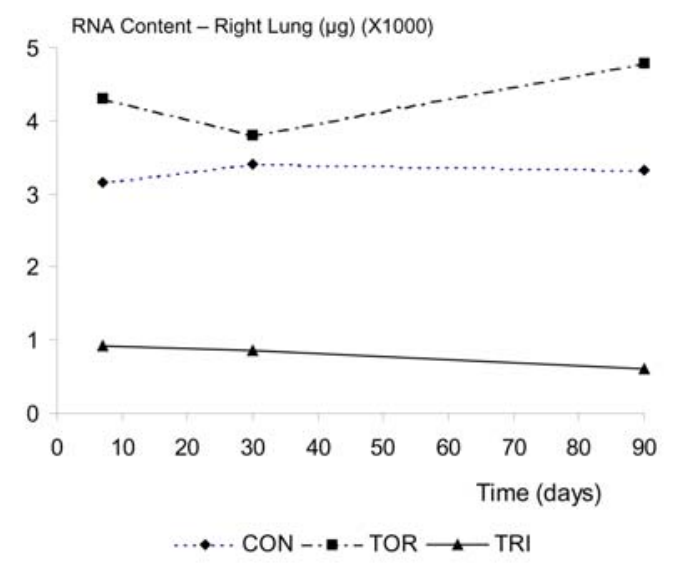

FIGURE 12 - RNA content in the right lung $(\mu \mathrm{g})(\mathrm{x} 1000)$. Treatment: $\mathrm{p}<0.05$; $(\mathrm{CON}=\mathrm{TOR})>$ TRI.

\section{Discussion}

\section{Protein content}

Analysis of cranial lobe protein content showed that CLG occurred though a very intense response in this lobe. In TRI rats this was always higher than the other groups at all three studied times (Figure 2). Even so the intensity of the response was not sufficient to compensate for the loss of the removed lobes, because right lung protein content of TRI rats, cranial lobes only, was always less than the other groups at all three studied times ${ }^{12}$ (Figure 4). In a similar study with young well-nourished rats, right lung protein content was always less in TRI rats, also showing that the cranial lobe on its own was not sufficient to compensate for the loss of the other lobes on the same side ${ }^{8,10}$. We saw that protein content in the left lungs of TRI rats was always higher than the other groups at all three studied times (Figure 3). Protein content in the lungs, the sum of left and right, was always less in TRI rats than the other groups at all three studied times (Figure 5). Therefore CLG after trilobectomy, even though seen in the cranial lobe and left lung, was not sufficient to make up for the loss. These results contrast with a study using young well-nourished TRI rats, because they showed full protein recuperation ${ }^{8,10}$. Studies which use adult well-nourished rats submitted to lung resection, show that lungs are capable of coordinating cellular proliferation and producing the protein components of the extracellular matrix. Both cellular division and production of these protein components are accompanied by a volume increase in the terminal air spaces, and also maintain the normal morphology of the remaining pulmonary parenchyma submitted to $C L G^{14}$. In our study, it seems that the nutritional deficit was a limiting factor for all these phenomena, by the simple lack of protein substrate in the reduced diet.

\section{DNA content}

DNA content in the cranial lobe was higher in TRI rats

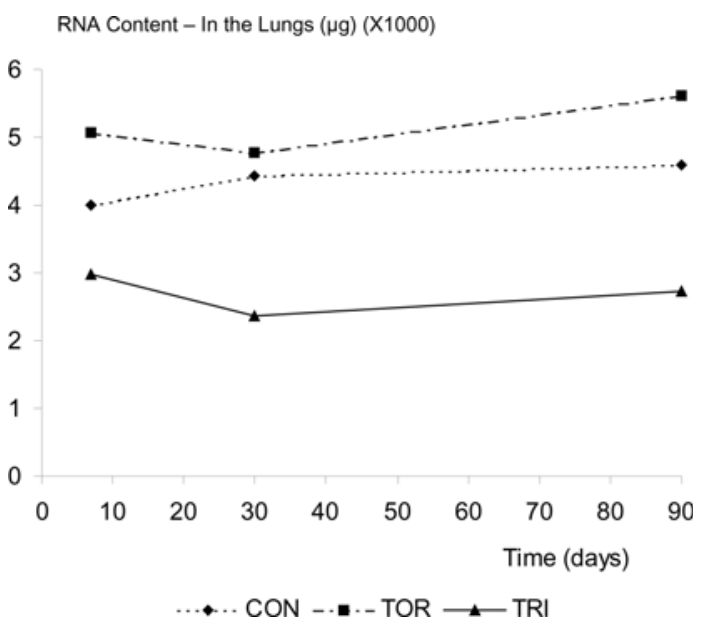

FIGURE 13 - RNA content of the lungs $(\mu \mathrm{g})(\mathrm{x} 1000)$. Treatment: $\mathrm{p}<0.05$; $(\mathrm{CON}=\mathrm{TOR})>$ TRI.

at the beginning and end of the experiment compared to the other groups (Figure 6). In young well-nourished TRI rats, DNA content in the cranial lobe tended to be higher, but at no time in the study was it significant ${ }^{10}$. Could undernutrition stimulate cellular multiplication?

In the left lung of TRI rats, DNA content was always higher than the other groups at all studied times demonstrating an intense compensatory response (Figure 7). CLG was demonstrated by the increase in DNA content which occurred despite undernourishment. Despite nutritional deficit, there was cellular multiplication after trilobectomy. Compensatory response in young wellnourished TRI rats was not complete, when represented by DNA content of the left lung ${ }^{10}$. DNA content of TRI rat lungs was always similar to TOR rats (Figure 9), even though $55 \%$ had been in the former, also hyperplasia seemed to occur from the initial moment. In well-nourished rats we were unable to demonstrate cellular multiplication with the same methodology. It seems that undernourishment acts as a facilitator of cellular hyperplasia.

\section{RNA content}

We observed that RNA content was always higher in the TRI rats (Figure 10). This was not sufficient to compensate for the loss of the three lobes, because in the right lung of TRI rats, cranial lobes only, it was always significantly less than the other groups at all three studied times. RNA content in young well-nourished TRI rats ${ }^{10}$ showed the same behaviour as undernourished animals, demonstrating that CLG, represented by increased RNA content, occurred in this lobe independent of nutritional state. In the left lung, RNA content was always higher in TRI rats (Figure 11), demonstrating that there was a compensatory response, although less intense than in the cranial lobe. This was similar to the well-nourished rats ${ }^{10}$. When analysing both lung, we see that in TRI rats, RNA content was always lower than the other groups at all three studied times (Figure 13). Therefore CLG represented by RNA content in the lungs was more efficient in the cranial 
lobe than the left lung, but both were not sufficient to recuperate this variable when compared to the other groups. Despite similar behaviour in well-nourished rats, in separate lung and both lung analysis, we could not achieve similar levels to the other undernourished groups, a fact which occurred in the well-nourished rats, demonstrating that even though there was a compensatory response for RNA content, it was not as efficient as in well-nourished rats ${ }^{10}$. In TRI rats in this experiment, we observed that protein, DNA, and RNA content were reduced (Figures 5, 9, and 13), some significantly when compared to the other groups. However, if we consider that more than half the lungs in TRI rats had been removed, there was effective CLG, despite undernourishment, with this phenomenon seeming to be much more important than normal rat growth, because there was practically no body mass gain throughout the whole experiment ${ }^{12}$. Due to CLG having occurred more as a result of DNA content rather than RNA or protein content, it seems that compensatory response in undernourished rats was more represented by cellular hyperplasia than hypertrophy, contrary to our previous study in well-nourished rats ${ }^{8,10}$.

\section{Conclusions}

In trilobectomized rats, DNA content recuperation in lung tissue was similar to those not submitted to lung resection. For RNA and protein content, in spite of CLG occurring in the remaining lobe and contra-lateral lung, it was not sufficient to reach the values of non-resection groups, suggesting that under these experimental conditions, in the adult undernourished rat, that CLG after trilobectomy occurs more by cellular hyperplasia than hypertrophy. This is very different from well-nourished rats, where hypertrophy was much more pronounced.

\section{References}

1. Association of Official and Agriculture Chemists. Official Methods of Analysis. 8a. Ed., Washington, 1965.

2. Cataneo AJM, Curi PR, Reibscheid SM. Alterações morfológicas do aparelho respiratório pós-trilobectomia pulmonar: estudo experimental no rato. J Pneumol. 1988; 14:121-6.

3. Cheek, DB, Holt AB, Hill, DE. Skeletal muscle cell mass and growth: the concept of the desoxyribonucleic acid unit. Pediatr Res. 1971; 5:312-28.

4. Dovat S, Gilbert KA, Petrovic-dovat L, Rannels DE. Targeted identification of zinc finger genes expressed in rat lung. Am J Physiol. 1998; 275:L30-L37.

5. Fisher LD. Biostatistics a methodology for the health sciences. New York: Wiley-Interscience, 1993.

6. Gilbert KA, Rannels DE. Increased lung inflation induces gene expression after pneumonectomy. Am J Physiol. 1998; 275:L21-L29.

7. Giles KW, Myers A. An improved diphenylamine method for the estimation of deoxyribonucleic acid. Nature. 1965; 206:93.

8. Koh DW, Roby JD, Starcher B, Senior RM, Pierce RA. Postpneumonectomy lung growth: a model of reinitiation of tropoelastin and Type I collagen production in a normal pattern in adult rat lung. Am J Respir Cell Mol Biol. 1996; 15:611-23.

9. Munro HN, Fleck A. The determination of nucleic acids. Methods biochem. Analysis. 1966; 14:114-76.

10. Rannels DE. Role of physical forces in compensatory growth of the lung. Am J Physiol. 1989; 257:L179-L189.

11. Ruiz Jr RL, Burini RC, Cataneo AJM. Compensatory lung growth: lung protein, DNA and RNA contents in trilobectomized rats. Acta Cir Bras. 1998; 13:18-25.

12. Ruiz Jr RL, Carvalho LR, Cataneo AJM. Crescimento Pulmonar Compensatório (CPC): Massa corpórea, conteúdo protéico e massa pulmonares em ratos subnutridos trilobectomizados. Acta Cir Bras. 2004; 19:148-54.

13. Ruiz Jr RL, Curi PR, Cataneo AJM. Compensatory lung growth: lung mass and protein contents in trilobectomized rats. Acta Cir Bras. 1996; 11:127-32.

14. Thet LA, Law DJ. Changes in cell number and lung morphology during early postpneumonectomy lung growth. J Appl Physiol. 1984; 56:975-8.

15. Zar JH. Biostatistical analysis. Englewood Cliffs: Prentice Hall, 1984.

\section{Correspondence:}

Raul Lopes Ruiz Júnior

Caixa Postal 501

18618-970 Botucatu - SP Brazil

ruizraul@fmb.unesp.br
Conflict of interest: none Financial source: none

Received: January 19, 2005

Review: February 15, 2005

Accepted: March 8, 2005

\section{How to cite this article:}

Ruiz Jr RL, Carvalho LR, Cataneo AJM. Compensatory lung growth: protein, DNA and RNA lung contents in undernourished trilobectomized rats. Acta Cir Bras. [serial online] 2005 May-June;20(3). Available from URL: http://www.scielo.br/acb 